\title{
SYSTEM PRODUCTIVITY OF POTATO + MAIZE INTERCROPPING AS AFFECTED BY SOWING DATE
}

\author{
A.A.Begum ${ }^{1}$, M.S.U.Bhuiya ${ }^{2}$, S.M.A. Hossain ${ }^{2}$, Amina Khatun ${ }^{3}$, S.K. Das ${ }^{4}$ and M.Y. Sarker ${ }^{5}$ \\ ${ }^{1}$ Agronomy Division, BARI, ${ }^{2}$ Department of Agronomy, BAU, ${ }^{3}$ RFS Division, BRRI, \\ ${ }^{4}$ Bangladesh Betar, Dhaka and ${ }^{5}$ BJRI, Dhaka \\ *Corresponding author: luckyshamol6869@gmail.com
}

Key word: Sowing date, shading, LAI, DM, CGR, equivalent yield, potato, maize, intercropping

\begin{abstract}
The experiment was conducted at Agronomy Research Field, Bangladesh Agricultural Research Institute (BARI), Gazipur during 2009-2010 to find out suitable sowing time of maize in potato + maize intercropping for maximum yield and economic return. Treatments of the experiment were: $\mathrm{T}_{1}=$ Simultaneous sowing (SS) of potato and hybrid maize (HM), $\mathrm{T}_{2}=\mathrm{SS}$ of potato and composite maize $(\mathrm{CM}), \mathrm{T}_{3}=\mathrm{HM}$ sown 10 days after potato planting (DAPP), $\mathrm{T}_{4}=\mathrm{CM}$ sown $10 \mathrm{DAPP}, \mathrm{T}_{5}=\mathrm{HM}$ sown $20 \mathrm{DAPP}, \mathrm{T}_{6}=\mathrm{CM}$ sown 20 DAPP, $\mathrm{T}_{7}=\mathrm{HM}$ sown 30 DAPP, $\mathrm{T}_{8}=\mathrm{CM}$ sown $30 \mathrm{DAPP}, \mathrm{T}_{9}=\mathrm{HM}$ sown 40 DAPP, $\mathrm{T}_{10}=\mathrm{CM}$ sown $40 \mathrm{DAPP}, \mathrm{T}_{11}=$ Sole potato, $\mathrm{T}_{12}=$ Sole HM and $\mathrm{T}_{13}=$ Sole $\mathrm{CM}$. The result revealed that sole potato and maize produced the highest yield, LAI, TDM and CGR. The HM showed better performance than CM. The highest equivalent yield and monetary return indicated that potato + HM sown 30 DAPP intercropping was the most productive and profitable.
\end{abstract}

\section{Introduction}

Intercropping is an important tool for getting higher productivity per unit area of land and it improves the food security (Mahfuza et al., 2012). Intercropping system becomes productive and economical only when it is done properly by selecting compatible crops (Begum et al., 2010), by shifting the period of peak demand for growth resources through changing the time of sowing of the component crops (Santalla et al., 1999) and when their component crops differ in photosynthetic pathway, growth habit, growth duration and demand for growth resources (Islam et al., 2007). Potato and maize may be grown as intercrop as they have different photosynthetic pathway, growth habit, growth duration and demand for growth resources. Potato is now becoming an important food for ensuring food security in Bangladesh. Conversely, maize (Zea mays L.) is the third most important food grain for human after rice and wheat. Maize in Bangladesh is becoming an important crop in the rice-based cropping pattern. In recent years maize is gaining popularity among the farmers mainly due to high yield, more economic return and versatile uses.

Sowing of component crops in different times is an important agronomic approach in intercropping systems but has not been extensively studied. Intercropping of 20-35 days after the planting of potato can bring very high profit, providing 20-21 t ha- ${ }^{-1}$ maize equivalent yield within five months (CIMMYT Office in Bangladesh, 2006). However, information relating sowing time of potato and maize in an intercropping system is very scarce. So, to understand the nature and extent of competition and complementarities of component crops, the experiment was undertaken to find out suitable sowing date of maize in potato maize intercropping for getting higher yield and economic return. 
Begum et al.

\section{Materials and Methods}

The experiment was conducted at the Agronomy research field of BARI, Gazipur during the Rabi season of 2009-2010. The soil of the experimental field was Chhiata clay loam having $\mathrm{pH} 6.49$, organic matter $1.08 \%$, total $\mathrm{N} 0.034(\%)$, potassium 0.18 meq/100g soil, phosphorus $13.5 \mathrm{ppm}$, sulphur $14.5 \mathrm{ppm}$, zinc $1.13 \mathrm{ppm}$ and boron $0.21 \mathrm{ppm}$. Maximum and minimum temperatures ranged from 24.11 to 35.13 and 11.21 to $25.45^{\circ} \mathrm{C}$, respectively, during the study period. Average monthly rainfall for this period was $45.00 \mathrm{~mm}$ where maximum rainfall was recorded $228.00 \mathrm{~mm}$ and minimum $8.00 \mathrm{~mm}$. Thirteen treatments were as follows: $\mathrm{T}_{1}=$ simultaneous sowing (SS) of potato and hybrid maize $(\mathrm{HM}), \mathrm{T}_{2}=\mathrm{SS}$ of potato and composite maize (CM), $\mathrm{T}_{3}=\mathrm{HM}$ sown 10 days after potato planting (DAPP), $\mathrm{T}_{4}=\mathrm{CM}$ sown $10 \mathrm{DAPP}, \mathrm{T}_{5}=$ $\mathrm{HM}$ sown 20 DAPP, $\mathrm{T}_{6}=\mathrm{CM}$ sown $20 \mathrm{DAPP}, \mathrm{T}_{7}=\mathrm{HM}$ sown $30 \mathrm{DAPP}, \mathrm{T}_{8}=\mathrm{CM}$ sown 30 DAPP, $\mathrm{T}_{9}=\mathrm{HM}$ sown 40 DAPP, $\mathrm{T}_{10}=\mathrm{CM}$ sown 40 DAPP, $\mathrm{T}_{11}=$ Sole potato, $\mathrm{T}_{12}=$ Sole $\mathrm{HM}$ and $\mathrm{T}_{13}=$ Sole $\mathrm{CM}$. The experiment was laid out in randomized complete block design with three replications. The size of a unit plot was $6.0 \mathrm{~m} \times 5.0 \mathrm{~m}$. Potato var. BARI Alu-8 (Cardinal) and maize var. BARI Hybrid maize-7 and BARI maize-7 (composite) were used in the experiment. Potato was planted on 20 November 2009. Sole potato and sole maize were also planted on the same date. Potato was planted with $60 \mathrm{~cm} \times 25 \mathrm{~cm}$ spacing in sole and $75 \mathrm{~cm} \times 20 \mathrm{~cm}$ spacing in intercrop situation. Maize was sown in $75 \mathrm{~cm} \times 20$ $\mathrm{cm}$ spacing both in sole and intercrop situation. In intercrop treatments, one row of maize accommodated in between two rows of potato. For sole potato, sole hybrid maize and sole composite maize fertilizers were applied @ $\mathrm{N}_{180} \mathrm{P}_{40} \mathrm{~K}_{180} \mathrm{~S}_{20} \mathrm{Zn}_{6} \mathrm{~B}_{1.2}$, $\mathrm{N}_{260} \mathrm{P}_{72} \mathrm{~K}_{148} \mathrm{~S}_{48} \mathrm{Zn}_{4} \mathrm{~B}_{2}$ and $\mathrm{N}_{160} \mathrm{P}_{50} \mathrm{~K}_{100} \mathrm{~S}_{40} \mathrm{Zn}_{4} \mathrm{~B}_{2} \mathrm{~kg} / \mathrm{ha}$, respectively (BARC, 2005). For intercrop fertilizers were applied @ $\mathrm{N}_{320} \mathrm{P}_{73} \mathrm{~K}_{170} \mathrm{~S}_{50} \mathrm{Zn}_{6} \mathrm{~B}_{2} \mathrm{~kg} /$ ha (Akhteruzzaman et al., 2008). The source of $\mathrm{N}, \mathrm{P}, \mathrm{K}, \mathrm{S}, \mathrm{Zn}$ and $\mathrm{B}$ was urea, triple super phosphate (TSP), Muriate of potash (MoP), gypsum, zinc sulphate and boric acid, respectively. In case of sole potato, half amount of urea, MoP and the whole amount of TSP, gypsum, zinc sulphate and boric acid were applied at the time of final land preparation. Remaining amount of urea and MoP were applied at 30 days after planting (DAP). For sole maize, one-third of urea and whole amount of other fertilizers were applied at the time of final land preparation. Remaining amount of urea was applied in two equal splits as side dressing at 30 and 55 days after sowing (DAS). In case of intercrop, one- third $(1 / 3)$ urea and of all other fertilizers were applied as basal. Onethird urea and rest of all other fertilizers were side dressed at 30 DAP of potato and rest of urea was side dressed just after potato harvest followed by irrigation. Four irrigations were given during the cropping period. First irrigation was given after potato planting, second at 30 DAPP, third at 55 DAPP and lastly at 95 DAPP (just after potato harvest). Fungicide (Dithane M-45) was sprayed at every 10-day intervals beginning from 25 to 70 DAP for preventing potato disease. Shading (\%) was computed by converting photo synthetically active radiation (PAR) and measured by PAR Ceptometer (Model - LP-80, Accu PAR, Decagon, USA) at 60, 68, 76, 84 and 92 DAPP at around 11:30 A.M. to 13:00 P.M. PAR was calculated using the following equation and expressed in percentage (Ahmed et al., 2010):

PAR int $\left(\% \neq \frac{\text { PAR inc-PART }}{\text { PAR inc }} \times 100\right.$

Where, PAR int $=$ intercepted PAR, PAR inc $=$ incident $\mathrm{PAR}$ and $\mathrm{PART}=$ transmitted PAR

Shading (\%) on underneath crop, PAR int (\%) by upper storied crop 
System Productivity of Potato + Maize Intercropping as Affected by Sowing Date

Plants were sampled at 15 day intervals from 30 days to maturity for potato and 20 day intervals from 30 to 130 days after sowing for maize and green leaf area was measured by an automatic leaf area meter (Model: LI-300, USA). Plant materials were oven dried at $70^{\circ} \mathrm{C}$ to a constant weight and dry weight taken. Crop growth rate of the component crops was computed by using the following equation (Gardner et al., 1985):

Crop growth rate $(\mathrm{CGR})=\left(\mathrm{W}_{2}-\mathrm{W}_{1}\right) /\left(\mathrm{T}_{2}-\mathrm{T}_{1}\right)$

Where, $\mathrm{W}=$ Weight of dry matter unit $^{-1}$ area and $\mathrm{T}=$ Time (days) and the subscripts 1 and 2 indicate measurements at time $T_{1}$ and $T_{2}$, respectively.

Potato was harvested on 24 February 2010 (95 DAP) and maize was harvested at 132-146 DAS. Yield of both crops were taken from whole plot. Potato equivalent yield was computed by converting yield of intercrops on the basis of prevailing market price of individual crop following the formula of Bandyopadhyay (1984) as given below:

Potato equivalent yield $=$ Yip $+($ Yim $\times$ Pm) $/ \mathrm{Pp}$

Where, Yip $=$ Yield of intercrop potato, Yim $=$ Yield of intercrop maize, $\mathrm{Pp}=$ Market price of potato and $\mathrm{Pm}=$ Market price of maize.

Collected data of both the crops were analyzed statistically and the means were adjudged using DMRT. Economic analysis was also done considering local market price of harvested crops.

\section{Results and Discussion}

\section{Plant shading (\%)}

Shading given by maize plants on underneath potato crops over time differed significantly at all the time intervals (Fig. 1). Shading increased progressively up to potato harvest. The highest shading (80\%) was observed in $\mathrm{T}_{1}$ (simultaneous sowing) at 90 DAP (Days After Planting) and the lowest shading in $T_{9}(52 \%)$ followed by $T_{10}$ (when maize sown $40 \mathrm{DAPP}$ ), $\mathrm{T}_{7} \& \mathrm{~T}_{8}$ (maize sown $30 \mathrm{DAPP}$ ). Similar trend was observed at all the intervals. Shading (20-70\%) was occurred by maize canopy on underneath potato crop during tuber bulking period (40-80 DAP) when maize was sown simultaneous with potato and 10 or 20 DAP of potato. On the other hand, 0$40 \%$ shading given by maize canopy during tuber bulking period (40-80 DAP) when maize was sown 30 and 40 DAPP and tuber bulking could start before shading given by maize plant and the degree of shading from 40 DAP onward was not exceed over $40 \%$ and more than $60 \%$ of the total incoming solar radiation transmitting through the maize canopy which was sufficient for continued rapid tuber bulking. The result revealed that planting date of maize intercropped with potato, maize sown on 30 days after planting of potato is suitable for intercropping. Maize grain yield was drastically reduced might be due to hot temperature at later growth stage. Ifenkwe and Odurukwe (1990) reported that potato yields increased with delayed sowing in association with maize while maize yields decreased as its sowing date was delayed.

Functional relationship between shading occurred by maize plant and tuber yield of potato indicated that tuber yield was negatively correlated to shading occurred by maize canopy in potato maize intercropping system (Fig. 2). The functional relationship suggested that $93 \%\left(\mathrm{R}^{2}=0.928\right)$ of the variation in yield of potato could be explained from the variation in shading. On an average, yield of potato could be decreased at the rate of $0.311 \mathrm{t} \mathrm{ha}^{-1}$ with an increase in $1 \%$ of shading. 
Begum et al.

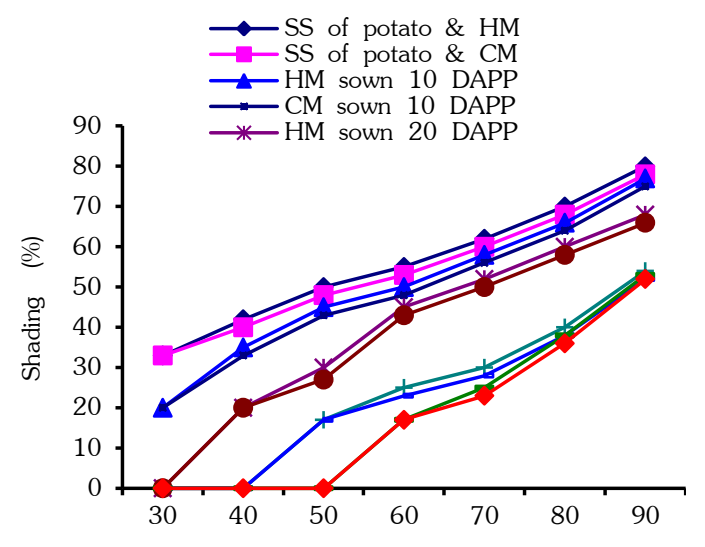

Days after planting

Fig. 1 Shading (\%) on potato by maize canopy in potato + maize intercropping systern over days after

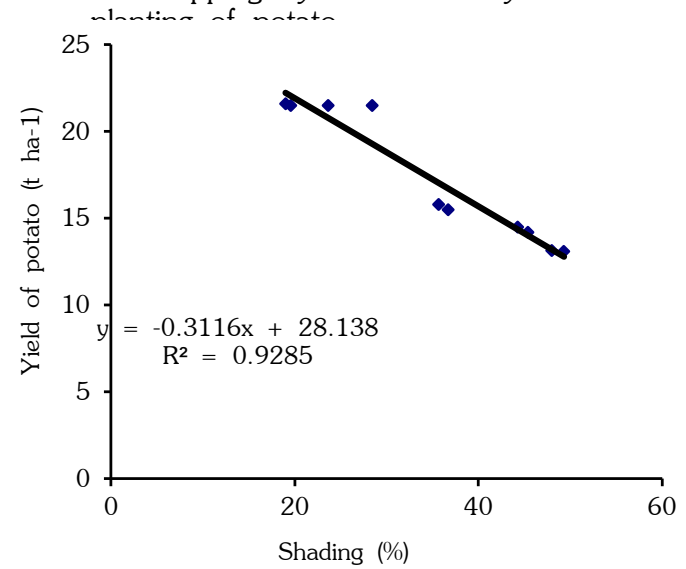

Fig. 2 Functional relationship between shading ocurred by maize plant and tuber yield of potato in potato maize intercropping

\section{Leaf area index of potato and maize}

Leaf area development in intercropped potato and maize are presented in Figs. 3 and 4. The LAI in potato and maize varied significantly in all the intervals up to harvest. The LAI increased sharply with the advancement of time up to 60 DAP in potato and 110 DAS in maize and thereafter decreased might be due to leaves senescence. The highest LAI (2.60) was observed in $\mathrm{T}_{11}$ (sole potato) at 60 DAP. LAIs of potato were similar in monoculture as well as when maize was intercropped with potato 30 and 40 DAPP and markedly differed when maize was intercropped simultaneous, 10 and 20 DAPP. 
System Productivity of Potato + Maize Intercropping as Affected by Sowing Date

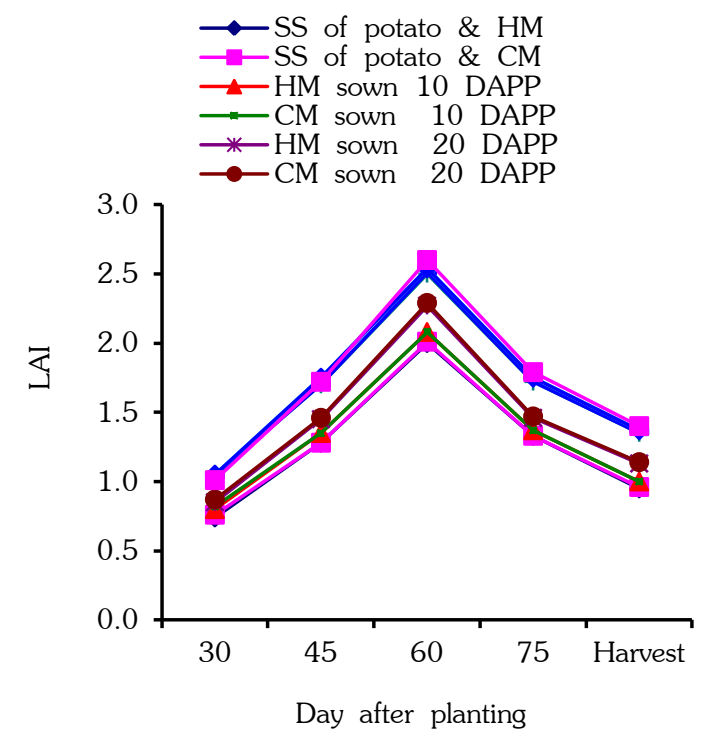

Fig. 3. LAI of potato in potato + maize intercropping
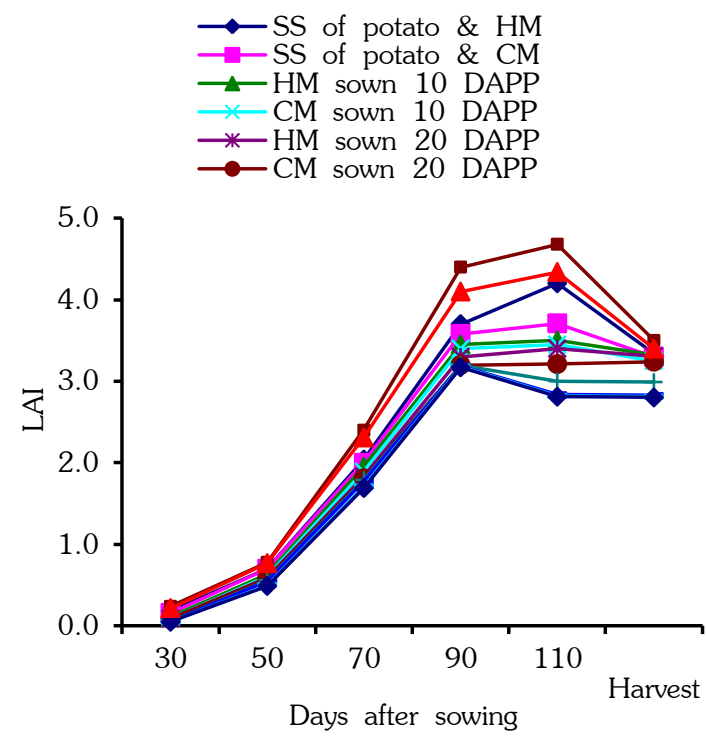

Fig. 4. LAI of maize in potato + maize intercropping

More or less similar result was observed by Islam (2002). LAI of maize was highest in monoculture which was closer to the LAI of maize grown simultaneously. But LAI of maize reduced considerably when it was sown 10, 20, 30 and 40 DAPP. Similar result was reported by Watiki et al. (1993) when cowpea was grown in association with maize. In all treatments the LAI of hybrid maize were higher than those of composite maize. It might be due to varietal character (Alam, 2003) due to different LAI in different varieties of maize.

\section{Total dry matter of potato and maize}

Total dry matter (TDM) of intercropped potato and maize increased progressively over time and there was significantly difference in the pattern of biomass accumulation at different sowing date of maize (Fig. 5 and 6). TDM increased sharply up to 60 DAP and 110 DAS in potato and maize, respectively, and then increased slowly up to harvest. Sole potato produced higher TDM than any other intercropped potato. Intercropped potato faced different levels of shading from different sowing dates of maize and subsequently accumulated lower dry matter (Kephart et al., 1992). The higher TDM of maize was found in monoculture and simultaneous sown with potato did not differ markedly but sharp difference occurred when maize was sown 10, 20, 30 and 40 DAPP. Total dry matter accumulation in pure stand maize and earlier sown were higher than those sown in later and the lowest dry matter was found when maize was sown 40 DAPP. Earlier sowing of maize showed better competitiveness of nutrients over late sown maize and reduced dry matter of late intercropped maize. The TDM of potato and maize was found positively correlated with tuber yield $(r=0.99)$ and grain yield $(r=0.67)$, respectively. 
Begum et al.

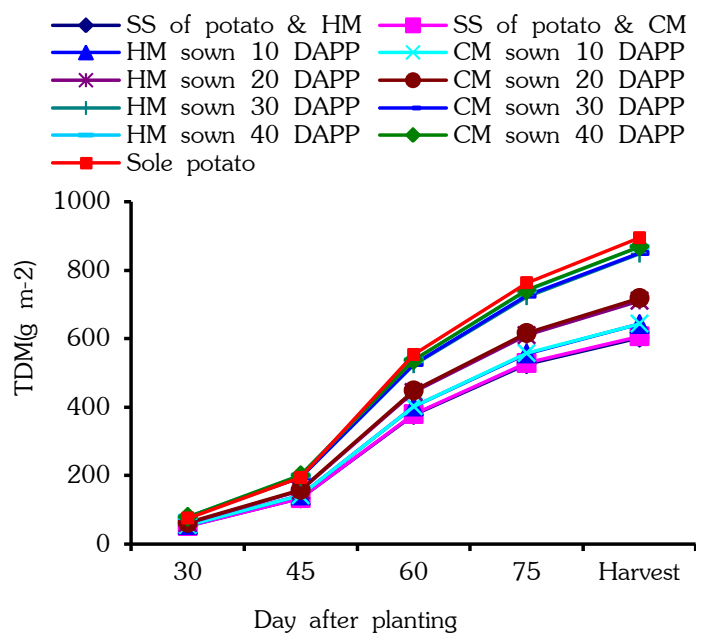

Fig. 5. TDM of potato in potato + maize Intercropping

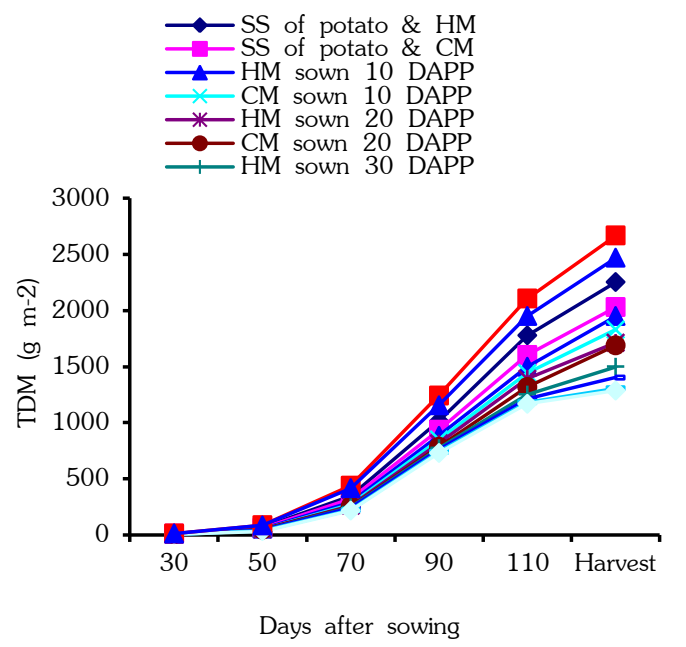

Fig. 6. TDM maize in potato + maize intercropping

\section{Crop growth rate of potato and maize}

Crop growth rate of potato increased sharply up to 60 DAP and thereafter declined rapidly till harvest. Crop growth rate of intercropped potato with maize sown at 30 and 40 days after potato planting were similar to that of sole potato. But it was significantly lower when maize was sown simultaneously or 10 and 20 DAPP. It might be due to reduction of leaf area and lower light availability to underneath potato canopy. Demagante and Zaag (1988a) reported that early shading (planting on wards) had a strong detrimental effect on tuber bulking rate with more shad. Irrespective of sowing date, CGR of maize (both varieties) increased progressively with time and reached peak at 110 DAS then declined till harvest in monoculture. Similar result was found by Alom (2007) and the earlier sowing of maize (simultaneous, 10 and 20 days after potato planting) reached peak at 110 DAS and delayed sown maize (30 and 40 DAPP) reached peak at 70-90 DAS. Earlier attainment of peak in dry matter accumulation in plant at late sown maize might be due to shortening of growth period with increase of temperature at later growth stage. There was a trend for higher CGR in sole cropping compared to the intercropped due to less competition among the plants for growth resources like nutrient, air, moisture, solar radiation etc. Kumar et al. (2000) also reported similar results. The CGR of potato and maize was found positively correlated with tuber yield $(r=0.98)$ and grain yield $(r=0.68)$, respectively. 
System Productivity of Potato + Maize Intercropping as Affected by Sowing Date

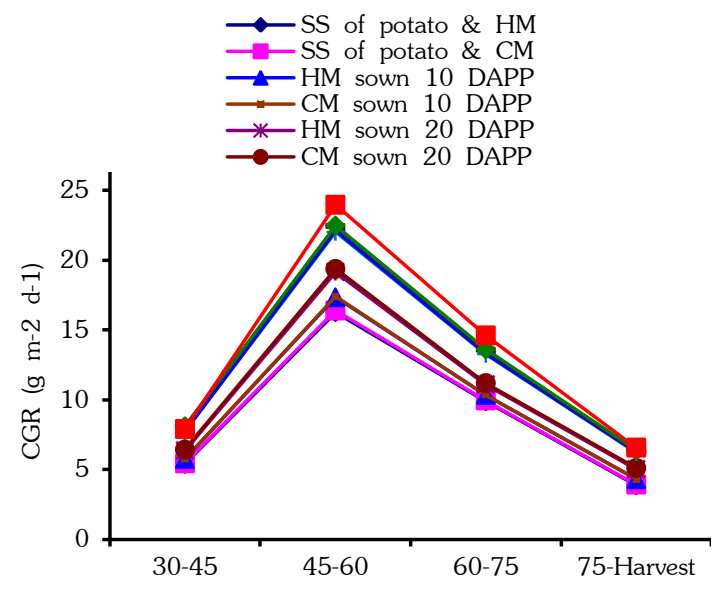

Fig. 7. CGR of potater planting potato + maize intercropping

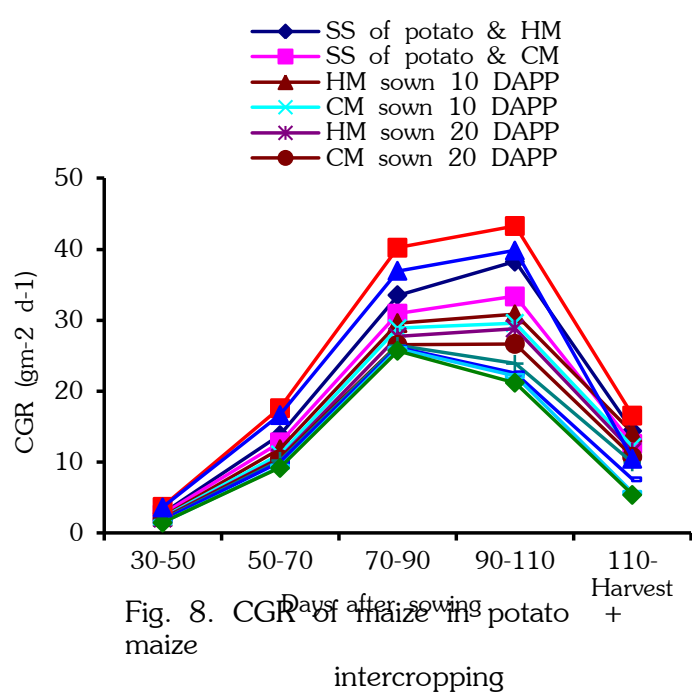

Yield and yield components of potato

Yield and yield components of potato were significantly affected in potato + maize intercropping (Table 1). Significant variation was observed in number of stems $\mathrm{m}^{-2}$, number of tubers hill ${ }^{-1}$, tuber weight hill ${ }^{-1}$ and tuber yield. The maximum number of stems $\mathrm{m}^{-2}$ was observed in sole potato $\left(\mathrm{T}_{11}\right)$ which was statistically similar with maize sown after 30 and 40 days of potato planting $\left(T_{7}, T_{8}, T_{9}\right.$ and $\left.T_{10}\right)$ and the lowest in potato + HM sown simultaneously $\left(T_{1}\right)$. Similar trend was observed in number of tubers hill ${ }^{-1}$, tuber weight hill $^{-1}$ and tuber yield. The maximum tuber yield of potato was recorded in sole potato $\left(22.50 \mathrm{t} \mathrm{ha}^{-1}\right)$ which was statistically similar with maize sown after 30 and 40 days of potato planting and it might be due to the earlybulging period of tuber which was shading free and cooling effect of shading during later growth stage of potato which favoured tuber bulging for longer period and ultimately increased tuber yield in maize sown 30 and 40 DAPP. Kuruppuarachchi (1990) also observed similar results in potato + maize intercropping. He reported that higher tuber yield where maize was sown delayed after potato planting. Maize sown simultaneously with potato gave the lowest tuber yield which was statistically similar with maize sown 10 DAPP. It might be due to lower light transmission during the tuber bulging period which reduced tuber yield. Tuber yield in different treatments were attributed to the cumulative effect of yield components.

Table 1. Yield and yield components of potato in potato maize intercropping as affected by sowing date of maize

\begin{tabular}{|c|c|c|c|c|c|}
\hline Treatments & $\begin{array}{l}\text { Hills } \mathrm{m}^{-2} \\
\text { (no.) }\end{array}$ & $\begin{array}{l}\text { Stems } \mathrm{m}^{-2} \\
\text { (no.) }\end{array}$ & $\begin{array}{l}\text { Tubers hill }{ }^{-1} \\
\text { (no.) }\end{array}$ & $\begin{array}{l}\text { Tubers wt. } \\
\text { hill }^{-1} \text { (g) }\end{array}$ & $\begin{array}{l}\text { Tuber yield } \\
\left(\mathrm{t} \mathrm{ha}^{-1}\right)\end{array}$ \\
\hline $\begin{array}{l}T_{1}=S S \text { of potato \& } \\
\mathrm{HM}\end{array}$ & 6.00 & $20.00 \mathrm{~d}$ & $5.50 c$ & $301.88 \mathrm{~d}$ & $13.10 \mathrm{c}$ \\
\hline $\begin{array}{l}\mathrm{T}_{2}=\mathrm{SS} \text { of potato \& } \\
\mathrm{CM}\end{array}$ & 6.20 & $20.00 \mathrm{~d}$ & $5.55 c$ & $301.25 \mathrm{~d}$ & $13.15 c$ \\
\hline $\begin{array}{l}\mathrm{T}_{3}=\mathrm{HM} \text { sown } 10 \\
\text { DAPP }\end{array}$ & 6.40 & $23.30 c$ & $5.93 b c$ & $335.12 c$ & $14.20 b c$ \\
\hline $\begin{array}{l}\mathrm{T}_{4}=\mathrm{CM} \text { sown } 10 \\
\text { DAPP }\end{array}$ & 6.40 & $23.33 c$ & $6.07 b c$ & $336.75 c$ & $14.50 \mathrm{~b}$ \\
\hline $\mathrm{T}_{5}=\mathrm{HM}$ sown 20 & 6.40 & $26.00 b$ & $6.20 b$ & $347.50 c$ & $15.50 b$ \\
\hline
\end{tabular}


Begum et al.

\begin{tabular}{lccccc} 
DAPP & & & & \\
$\mathrm{T}_{6}=\mathrm{CM}$ sown 20 & 6.50 & $26.18 \mathrm{~b}$ & $6.30 \mathrm{~b}$ & $348.75 \mathrm{c}$ & $15.80 \mathrm{~b}$ \\
$\mathrm{DAPP}$ & 6.50 & $31.55 \mathrm{a}$ & $8.40 \mathrm{a}$ & $495.75 \mathrm{~b}$ & $21.50 \mathrm{a}$ \\
$\mathrm{T}_{7}=\mathrm{HM}$ sown 30 & 6.70 & $31.66 \mathrm{a}$ & $8.45 \mathrm{a}$ & $495.72 \mathrm{~b}$ & $21.50 \mathrm{a}$ \\
$\mathrm{DAPP}$ & & & & & \\
$\mathrm{T}_{8}=\mathrm{CM}$ sown 30 & 6.70 & $32.00 \mathrm{a}$ & $8.50 \mathrm{a}$ & $501.10 \mathrm{~b}$ & $21.50 \mathrm{a}$ \\
DAPP & & & & & \\
$\mathrm{T}_{9}=\mathrm{HM}$ sown 40 & 6.70 & $32.66 \mathrm{a}$ & $8.60 \mathrm{a}$ & $501.12 \mathrm{~b}$ & $21.60 \mathrm{a}$ \\
DAPP & & & & & \\
$\mathrm{T}_{10}=\mathrm{CM}$ sown 40 & 6.70 & $33.33 \mathrm{a}$ & $8.80 \mathrm{a}$ & $535.70 \mathrm{a}$ & $22.50 \mathrm{a}$ \\
DAPP & $\mathrm{NS}$ & 0.01 & 0.01 & 0.01 & 0.01 \\
$\mathrm{~T}_{11}=$ Sole potato & 4.05 & 3.42 & 3.61 & 3.45 & 4.70 \\
\hline Level of Significance & &
\end{tabular}

In a column figures having common letter (s) do not differ significantly as per DMRT

Yield and yield components of maize

Yield and yield components viz., number of cobs $\mathrm{m}^{-2}$, number of grains $\mathrm{cob}^{-1}, 1000$ grain weight and grain yield of maize were influenced significantly under different intercropping (Table 2). The maximum cobs $\mathrm{m}^{-2}$ (6.13) was recorded in $\mathrm{T}_{12}$ (sole hybrid maize) which was followed by $T_{1}$. The lowest number of cobs $\mathrm{m}^{-2}(5.33)$ was recorded in $\mathrm{CM}$ sown $40 \mathrm{DAPP}$. There was no significant variation observed when maize was intercropped with potato but it reduced gradually with delayed sown of maize. It might be due to lower number of maize population. In delayed sown maize, germination of maize was affected and seedlings growth was hampered due to heavy shade of potato canopy. As a result, poor growth as well as lower number of cobs $\mathrm{m}^{-2}$ was observed. Similar result was observed by Zaag and Demagante, 1990. Number of cobs $\mathrm{m}^{-2}$ of maize was found positively correlated with grain yield $(\mathrm{r}=$ 0.94). The highest number of grains $\mathrm{cob}^{-1}$ and 1000 -grain weight were observed in sole hybrid maize which was statistically different from all other treatments (Table 2). In general, the highest number of grains $\mathrm{cob}^{-1}$ was observed in monoculture due to the plants having more space, light and nutrient in sole cropping (Moula et al., 2000). On the other hand, it was decreased in intercropped situation depending upon the sowing times (Table 2). Number of grains $\mathrm{cob}^{-1}$ gradually reduced with delaying sown of maize. It might be associated with intense competition for growth resources and high temperature at later growth stage (Islam, 2002). Grain yield of maize almost resembled to its yield contributing characters observed sown at different dates with potato (Table 2). The maximum grain yield (11.26 $\left.\mathrm{t} \mathrm{ha}^{-1}\right)$ was observed in sole hybrid maize which was statistically at par with hybrid maize simultaneous sowing with potato. It showed that hybrid maize and respective intercrops were higher yielder which might be due to cumulative effect of better yield attributes. On the other hand, composite maize and respective intercrops were lower yielder might be due to poor yield attributes. Higher yield of maize was observed in monoculture compared to respective intercropped might be due to no intercrop competition for light, nutrients, moisture and space. Yield of maize was gradually decreased with delaying sowing due to hot temperature that shortening the growth period at later stage. Ifenkwe and Odurukwe (1990) also reported that potato yields increased with delay sowing in association with maize while maize yields decreased as its sowing date was delayed.

Table 2. Grain yield and yield components of maize in potato +maize intercropping as affected by sowing date of maize

\begin{tabular}{ccccc} 
Treatments & $\begin{array}{c}\text { Cobs } \mathrm{m}^{-2} \\
\text { (no.) }\end{array}$ & $\begin{array}{c}\text { Grains } \mathrm{cob}^{-1} \\
\text { (no.) }\end{array}$ & $\begin{array}{c}1000 \text {-grain } \\
\text { wt.(g) }\end{array}$ & $\begin{array}{c}\text { Grain yield } \\
(\mathrm{t} \mathrm{ha})\end{array}$ \\
\hline
\end{tabular}


System Productivity of Potato + Maize Intercropping as Affected by Sowing Date

\begin{tabular}{lcccc}
\hline $\mathrm{T}_{1}=\mathrm{SS}$ of potato \& & $5.97 \mathrm{a}$ & $535.18 \mathrm{~b}$ & $347.53 \mathrm{ab}$ & $9.43 \mathrm{ab}$ \\
$\mathrm{HM}$ & & & & \\
$\mathrm{T}_{2}=\mathrm{SS}$ of potato \& CM & $5.45 \mathrm{c}$ & $398.87 \mathrm{de}$ & $346.90 \mathrm{ab}$ & $6.00 \mathrm{de}$ \\
$\mathrm{T}_{3}=\mathrm{HM}$ sown 10 DAPP & $5.92 \mathrm{a}$ & $500.40 \mathrm{bc}$ & $342.25 \mathrm{~b}$ & $9.07 \mathrm{~b}$ \\
$\mathrm{~T}_{4}=\mathrm{CM}$ sown 10 DAPP & $5.45 \mathrm{c}$ & $380.91 \mathrm{de}$ & $340.63 \mathrm{~b}$ & $5.60 \mathrm{de}$ \\
$\mathrm{T}_{5}=\mathrm{HM}$ sown 20 DAPP & $5.92 \mathrm{a}$ & $483.53 \mathrm{bc}$ & $335.50 \mathrm{~b}$ & $8.57 \mathrm{bc}$ \\
$\mathrm{T}_{6}=\mathrm{CM}$ sown 20 DAPP & $5.40 \mathrm{c}$ & $371.67 \mathrm{e}$ & $332.63 \mathrm{~b}$ & $5.36 e$ \\
$\mathrm{~T}_{7}=\mathrm{HM}$ sown 30 DAPP & $5.87 \mathrm{a}$ & $470.53 \mathrm{bc}$ & $327.65 \mathrm{~b}$ & $8.17 \mathrm{bc}$ \\
$\mathrm{T}_{8}=\mathrm{CM}$ sown 30 DAPP & $5.35 \mathrm{c}$ & $355.20 e$ & $324.72 \mathrm{~b}$ & $5.00 \mathrm{e}$ \\
$\mathrm{T}_{9}=\mathrm{HM}$ sown 40 DAPP & $5.81 \mathrm{ab}$ & $450.58 \mathrm{~cd}$ & $320.04 \mathrm{~b}$ & $6.75 \mathrm{cde}$ \\
$\mathrm{T}_{10}=\mathrm{CM}$ sown 40 & $5.33 \mathrm{c}$ & $345.25 e$ & $319.15 \mathrm{~b}$ & $4.70 \mathrm{e}$ \\
$\mathrm{DAPP}$ & & & & \\
$\mathrm{T}_{12}=$ Sole HM & $6.13 \mathrm{a}$ & $610.20 \mathrm{a}$ & $376.77 \mathrm{a}$ & $11.26 \mathrm{a}$ \\
$\mathrm{T}_{13}=$ Sole CM & $5.50 \mathrm{bc}$ & $500.00 \mathrm{bc}$ & $350.33 \mathrm{ab}$ & $7.50 \mathrm{bcd}$ \\
\hline $\mathrm{Level} \mathrm{of} \mathrm{Significance}$ & 0.01 & 0.01 & 0.01 & 0.01 \\
$\mathrm{CV}(\%)$ & 2.54 & 6.82 & 4.26 & 12.37 \\
\hline
\end{tabular}

In a column figures having common letter (s) do not differ significantly as per DMRT

\section{Intercrop efficiency}

Potato equivalent yield (PEY) and economic performance of potato + maize intercropping have been presented in Table 3. Intercrop productivity was evaluated by equivalent yield (Bandyopadhyay, 1984). The highest PEY (31.30 t ha $\left.{ }^{-1}\right)$ was observed when hybrid maize sown at 30 DAPP. Monetary advantage was estimated following Shah et al. (1991). The highest gross return (Tk. 426925 ha $^{-1}$ ), gross margin (Tk. $282680 \mathrm{ha}^{-1}$ ) and benefit cost ratio (2.79) were observed in the same treatment $\mathrm{T}_{7}$ (HM sown 30 DAPP).

Table 3. Equivalent yield and economic performance of the component crops in potato maize intercropping as affected by sowing date of maize

\begin{tabular}{lccccc}
\hline Treatments & $\begin{array}{c}\text { Potato equivalent } \\
\text { yield }\left(\mathrm{t} \mathrm{ha}{ }^{-1}\right)\end{array}$ & $\begin{array}{c}\text { Gross } \\
\text { return (Tk. } \\
\left.\text { ha }^{-1}\right)\end{array}$ & $\begin{array}{c}\text { Cost of } \\
\text { cultivation } \\
(\text { Tk. ha }\end{array}$ & $\begin{array}{c}\text { Gross margin } \\
\left(\text { Tk. ha }^{-1}\right)\end{array}$ & $\begin{array}{c}\text { Benefit } \\
\text { cost ratio }\end{array}$ \\
\hline $\mathrm{T}_{1}$ & 24.47 & 244700 & 112322 & 132378 & 2.18 \\
$\mathrm{~T}_{2}$ & 20.30 & 203000 & 112322 & 90678 & 1.81 \\
$\mathrm{~T}_{3}$ & 25.08 & 250800 & 112322 & 138478 & 2.23 \\
$\mathrm{~T}_{4}$ & 20.92 & 209200 & 112322 & 96878 & 1.86 \\
$\mathrm{~T}_{5}$ & 25.78 & 258800 & 112322 & 146478 & 2.30 \\
$\mathrm{~T}_{6}$ & 22.23 & 222300 & 112322 & 109978 & 1.98 \\
$\mathrm{~T}_{7}$ & 31.30 & 313000 & 112322 & 200678 & 2.79 \\
$\mathrm{~T}_{8}$ & 27.50 & 275000 & 112322 & 162678 & 2.45 \\
$\mathrm{~T}_{9}$ & 29.60 & 296000 & 112322 & 183678 & 2.64 \\
$\mathrm{~T}_{10}$ & 27.24 & 272400 & 112322 & 160078 & 2.43 \\
$\mathrm{~T}_{11}$ & 22.50 & 225000 & 97943 & 127057 & 2.30 \\
$\mathrm{~T}_{12}$ & 13.51 & 135100 & 62020 & 73080 & 2.18 \\
$\mathrm{~T}_{13}$ & 9.00 & 90000 & 57690 & 32310 & 1.56 \\
\hline
\end{tabular}

Market price $\left(T k . \mathrm{kg}^{-1}\right)$ : Potato 10 , maize 12 .

\section{Conclusion}

Hybrid maize sown 30 days after potato planting was found the most productive and profitable intercropping system for getting higher potato equivalent yield and monetary advantage without affecting the main crop yield. 
Begum et al.

\section{References}

Ahmed, F., M. N. Islam, M. T. Rahman, M. A. Jahan and M. S. A. Khan. 2010. Leaf area index, radiation interception, dry matter production and grain yield of hybrid maize as influenced by plant spacing. Bangladesh Agron. J. 13(1\&2): 51-58.

Alam, M. Z. 2003. Influence of planting dates and nitrogen levels on growth, grain yield and nitrogen utilization of barley. $\mathrm{PhD}$ Dissertation, Crop Physiology Laboratory, Dept. Botany, Rajshahi Univ., Bangladesh.

Alom, M. S. 2007. Performances of different hybrid maize (Zea mays L.) varieties under intercropping systems with groundnut (Arachis hypogaea L.) and mungbean (Vigna radiata L.). PhD Thesis, Dept. of Botany, Rajshahi Univ., Rajshahi, Bangladesh.

Akhteruzzaman, M., M. N. Islam, B. L. Nag and M. T. Rahman. 2008. Productivity of potato-hybrid maize intercropping under different fertilizer levels. Eco-Friendly Agril. J. 1(5): 300-303.

Bandyopadhyay, S. N. 1984. Nitrogen and water relations in grain sorghum-legume intercropping systems. Ph.D. Dissertation, Indian Agril. Res. Inst., New Delhi.

BARC (Bangladesh Agricultural Research Council). 2005. Fertilizer Recommendation Guide. Bangladesh Agril. Res. Coun. (BARC), Farmgate, Dhaka-1215. Pp.73-99.

Begum, S., M. N. Islam, M. T. Rahman, J. A. Chowdhury and M. I. Haque. 2010. Suitability study of different chilli varieties for intercropping with sweet gourd. J. Expt. Bios. 1(2): 1-4.

CIMMYT Office in Bangladesh. 2006. Maize whole family training. In: Food Security in Bangladesh: Improving Wheat, Maize and Papaya Production and Impacts of Arsenic Contamination. Project Annual Report for 2005-2006. Pp. 31-44.

Demagante, A. L. and V. P. Zaag. 1988. The response of potato (Solanum spp.) to photoperiod and light intensity under high temperatures. Potato Res. 31: 73-83.

Gardner, F. P., R. B. Pearce and R. L. Mitchell (eds.). 1985. Growth and Development. Physiology of Crop Plants. Lowa state Univ. Press, Ames, USA. Pp.187-208.

Ifenkwe, O. P. and S. O. Odurukwe. 1990. Potato/maize intercropping in the Jos Plateau of Nigeria. Field Crops Res. 25: 73-82.

Islam, M. N. 2002. Competitive interference and productivity in maize-bushbean intercropping system. Ph.D. Dissertation, Dept. Agron., Bangabandhu Sheikh Mujibur Rahman Agril. Univ., Gazipur, Bangladesh.

Islam, M. N., M. A. Hossain, M. S. A. Khan, B. L. Nag, M. A. I. Sarker, M. T. Rahman and I. M. Ahmed. 2007. Fertilizer management in hybrid maize- sweet potato intercropping systems. Bangladesh J. Crop Sci. 18(1): 89-94.

Kephart, K. D., D. R. Buxton and S. E. Taylor. 1992. Growth of $\mathrm{C}_{3}$ and $\mathrm{C}_{4}$ perennial grasses in reduced irradiance. Crop Sci. 32: 1033-1038.

Kumar, C. A., S. Kumar, G. P. Srivastava and S. Kumar. 2000. Production potential and fertilizer economy in winter maize + potato based intercropping system. Orissa J. Hort. 28(1): 51-55.

Kuruppuarachchi, D. S. P. 1990. Intercropped potato (Solanum spp.): Effect of shade on growth and tuber yield in the northwestern recosol belt of Sri Lanka. Field Crops Res. 25: 61-72.

Mahfuza, S. N., M. N. Islam, A. Hannan, M. Akhteruzzaman, and S. Begum. 2012. Intercropping 
System Productivity of Potato + Maize Intercropping as Affected by Sowing Date $77-82$

different vegetables and spices with pointed gourd. J. Expt. Biosci. 3(1):

Moula, M. G., S. Begum, M. A. Rahman and M. A. Quayyum. 2000. Effect of row spacing and nitrogen levels on the yield and yield attributes of maize. Bangladesh J. Agril. Sci. 27: 5-6.

Santalla, M., P. A. Casquero, A.M. de Ron. 1999. Yield and yield components from intercropping improved bush bean cultivars with maize. Agron. Crop Sci. 183: 263-269.

Shah, N. H., P. K. Koul, B. A. Khanday and D. Kachrov. 1991. Production potential and monetary advantage index of maize intercropped with different grain legumes. Indian J. Agron. 36(1): 23-28.

Watiki, J. M., S. Fukai, J. A. Banda and B. A. Keating. 1993. Radiation interception and growth of maize/cowpea intercrop as affected by maize plant density and cowpea cultivar. Field Crops Res. 35: 123-133.

Zaag, V. P. and A .L. Demagante. 1990. Potato (Solanum spp.) in an isohyperthermic environment. V. Intercropping with maize. Field Crops Res. 25: 157-170. 